\title{
Interfaces
}

\section{Visual Sociology of the Vernacular Urban Landscape: An Interview with Jerome Krase}

Jerome Krase, Jordi Ballesta and Eliane de Larminat

\section{(2) OpenEdition}

1 Journals

Electronic version

URL: https://journals.openedition.org/interfaces/1856

DOI: 10.4000/interfaces.1856

ISSN: 2647-6754

Publisher:

Université de Bourgogne, Université de Paris, College of the Holy Cross

Printed version

Date of publication: 15 December 2020

Number of pages: 145-167

ISSN: 1164-6225

\section{Electronic reference}

Jerome Krase, Jordi Ballesta and Eliane de Larminat, "Visual Sociology of the Vernacular Urban

Landscape: An Interview with Jerome Krase", Interfaces [Online], 44 | 2020, Online since 15 décembre 2020, connection on 28 juin 2022. URL: http://journals.openedition.org/interfaces/1856 ; DOI: https:// doi.org/10.4000/interfaces.1856

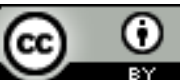

Les contenus de la revue Interfaces sont mis à disposition selon les termes de la Licence Creative Commons Attribution 4.0 International. 


\title{
VISUAL SOCIOLOGY OF THE VERNACULAR URBAN LANDSCAPE: AN INTERVIEW WITH JEROME KRASE
}

\author{
Jerome Krase \\ Brooklyn College of The City University of New York \\ Jordi Ballesta \\ Université Jean Monnet, CIEREC \\ Eliane de Larminat \\ Université de Paris, LARCA
}

\begin{abstract}
Visual sociologist Jerome Krase looks at how cities change with immigration, globalization, and gentrification, with a focus on Brooklyn as well as comparative work in cities around the world. He focuses on what can be learned through direct observation of the vernacular landscapes of neighborhoods where the interface between the public and private domains is individually and communally appropriated. He has argued consistently that ordinary residents have the power to change the meaning of a place by changing how it looks. His sociological practice has involved photography for decades, and he has developed a large visual archive of urban neighborhoods around the world. This illustrated interview focuses on the articulation of domestic, commercial, and real-estate practices, especially in Brooklyn, New York, and on the displacements, exchanges, and adaptations that characterize both vernacular agency and the academic use of the concept of "vernacular" across the social sciences.
\end{abstract}

Keywords: vernacular, visual sociology, photography, immigration, Brooklyn, rephotography, commercial strips, Italian-American neighborhoods, Jackson (John Brinckerhoff)

Résumé : Le sociologue visuel Jerome Krase regarde comment les villes changent sous l'effet de l'immigration, de la mondialisation et de la gentrification, en se concentrant surtout sur Brooklyn, mais également à partir d'un travail comparatif mené dans de nombreuses villes du monde. Il s'intéresse à ce que l'observation directe des paysages vernaculaires peut apprendre, en particulier dans des quartiers où les activités sociales se déploient à l'interface des espaces public et privé. Dans l'ensemble de son travail, il montre comment des résidents ordinaires ont le pouvoir de changer le sens d'un espace en changeant son aspect. Depuis des décennies, sa sociologie est fondée sur une pratique photographique, grâce à laquelle il a constitué une vaste archive visuelle. Cet entretien illustré se concentre sur l'articulation des pratiques domestiques, commerciales et immobilières (en particulier à Brooklyn), et sur les déplacements, échanges et adaptations qui sous-tendent à la fois les manières de faire vernaculaires et l'usage académique de la notion de "vernaculaire" dans plusieurs disciplines des sciences sociales. Mots-clefs : vernaculaire, sociologie visuelle, photographie, immigration, Brooklyn, rephotographie, commercial strips, quartiers italo-américains, Jackson (John Brinckerhoff) 


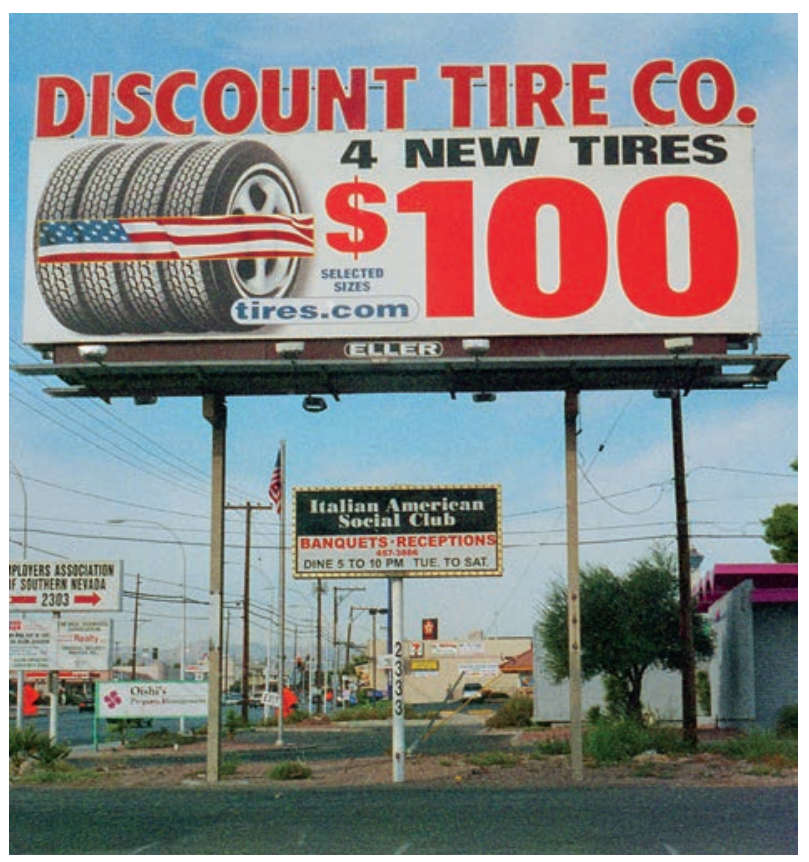

Figure 1. Italian American Social Club, Las Vegas, Nevada, 2001.

While at an American Italian Historical Association Conference in Las Vegas, Nevada I photographed as I walked several miles down The Strip and came upon a very Las Vegas-like proliferation of signs at an intersection; with these framing "the Italian American Social Club."

(C) Jerry Krase. 


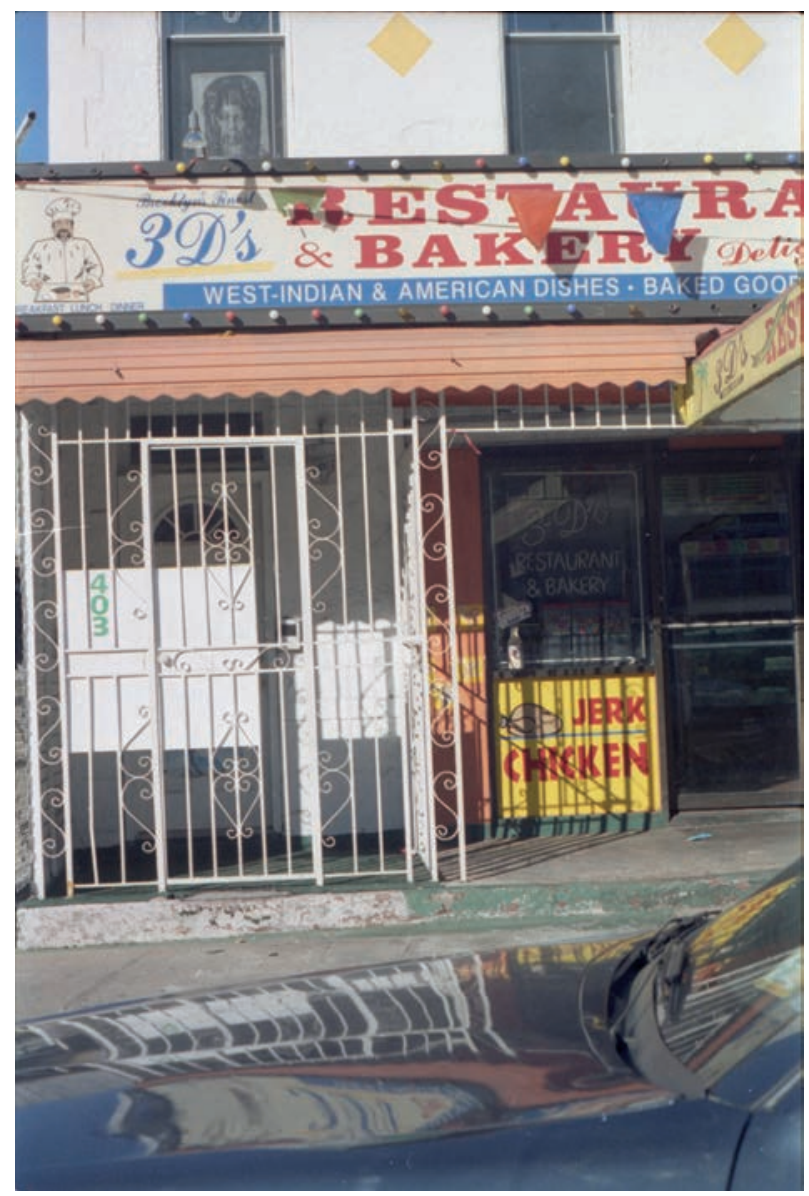

Figure 2. 3 D's West Indian Restaurant \& Bakery, Caribbean American Enclave, Crown Heights, Brooklyn, New York, 2001.

One of the most powerful ways that ethnic groups signal their dominance of a neighborhood is through the signage and other visual elements of the commercial vernacular landscapes they create. In this snapshot taken from a slowly passing car in which I was a passenger, there are many visual clues such as the obvious name. Less obvious, perhaps to those uninformed about West Indian cuisine, is the "Jerk Chicken" sign. (C) Jerry Krase. 


\section{The vernacular in the urban landscape}

Jordi Ballesta and Eliane de Larminat: Among the authors that you use as references to explain your acceptation of "the vernacular," John Brinckerhoff Jackson has pride of place. Could you tell us in what ways his own conception of the vernacular has influenced - and still influences - your work?

Jerome Krase: My discovery of “the vernacular," and Jackson's work, was serendipitous, as I was looking for a concept that would allow me to translate my visual sociological studies of ethnic neighborhoods, in the first case, Italian ones, for the readers of Places - which is a journal on architecture, landscape, and urbanism and whose audience includes designers, artists, and photographers. Jackson provided me with a vivid description of the American vernacular dwelling that I could use to compare to that of non-Americans (Jackson 86-87; see also Scully). More broadly, he enticed me to critically examine what "lies underneath below the symbols of permanent power expressed in the "Political Landscape"' (Jackson 6). As opposed to the insight provided by merely examining the role of "polite" architecture in social history, he clearly understood that what ordinary people do in particular physical territories and how they use objects therein are critical for understanding the space. Jackson's work fits neatly into the long tradition of ethnographic methods used in the study of urban neighborhoods, which however paid almost all attention to aural data, such as interviews, rather than visual appearances. I argued that the overlooked, sometimes subtle, visual appearances of neighborhoods were also important for understanding both the local situation and their national and transnational context. Furthermore, these appearances were also important for how the neighborhood, and its inhabitants, were treated by outsiders such as mortgage lenders and municipal authorities. Another unexpected outcome of that article was correspondence with noted cultural geographer Wilbur Zelinsky. At first he disagreed with my view on the relative power of ethnic vernacular landscapes, as he offered that there are no meaningful ethnic landscapes. Indeed, he had earlier written that "ethnic markers,' such as distinctive shop signs, exotic religious objects in yards or on porches, ephemeral festival decorations [...], or startling new color patterns for houses" were "merely cosmetic" (Zelinsky 1973, 8). This apparent dismissal was really a caution expressed by Zelinsky, as by others, that excessive attention devoted to these signs could lead to an overestimation of the power of relatively powerless urban dwellers. But he eventually referenced my work on Italian and Polish American vernacular landscapes in his own exploration of landscapes of cultural and social geography (Zelinsky 2000, 72-74; 102-3).

JB/EL: In the study of architecture and of material cultures, the notion of vernacular often interacts with those of ordinary, indigenous, domestic, even pioneer. It is sometimes associated with the notions of precarious, informal, and spontaneous. These last three words suggest that the vernacular tends to 
operate outside the control of political decisions and to produce unstable forms. How do you position yourself in relation to those different notions, and why do you favor the notion of "vernacular"?

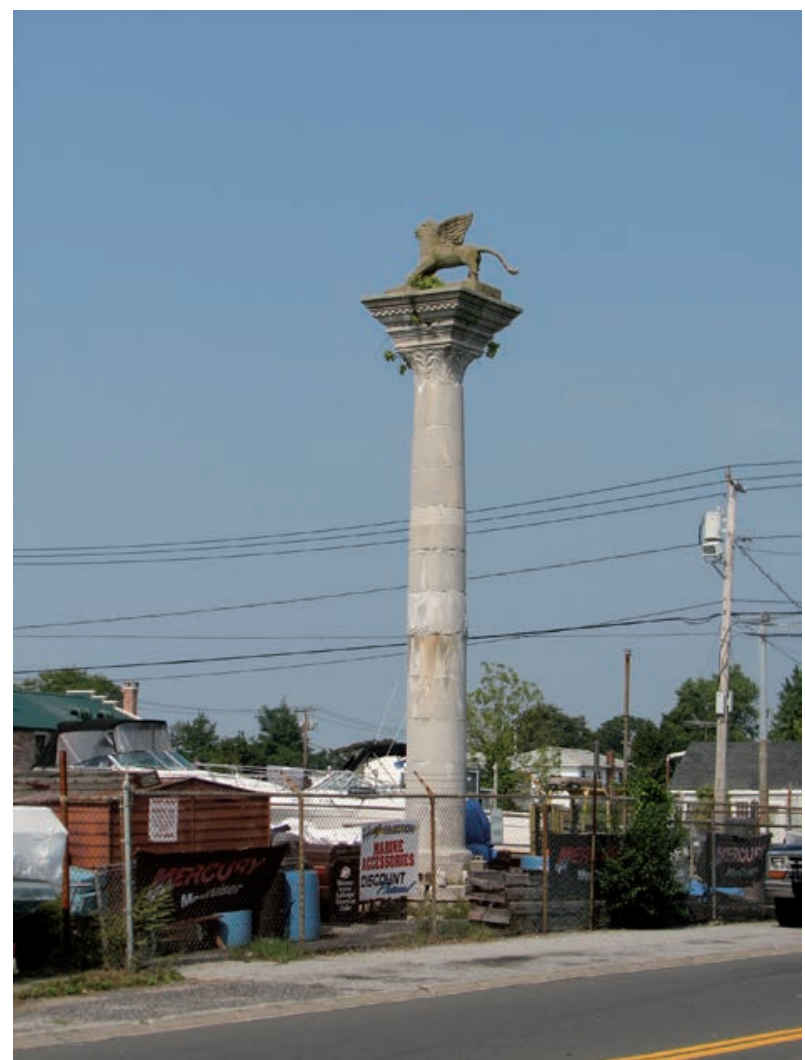

Figure 3. Colonnade, American Venice, Italian American Enclave, Copiague, Long Island, 2015.

On a trip to document "American Venice," a residential development created in the 1920s in Copiague, New York, I found these winged lions atop a colonnade near the entrance to the community. They are symbols of Saint Mark, the patron saint of Venice, and a replication of the column in Venice's Piazza San Marco.

$$
\text { (C) Jerry Krase. }
$$


JK: Although many of the urban scenes which I have studied might be described as precarious, informal, and spontaneous, those terms, as they are interpreted by social scientists like myself, are not precise enough for analysis, except for "informal". For example, the precarity of the vernacular landscapes of poverty is significantly different from that of immigrants whose class position has a great range in the USA. One major problem of doing trans- and interdisciplinary scholarship is that the data collection methods and findings may not be as easily transferrable from one research context to another as some researchers may think, especially where different countries and cultures are concerned. As noted by pioneering visual sociologist Howard S. Becker, the differences between "Visual Sociology, Documentary Photography, and Photojournalism [Are] Almost All a Matter of Context" (Becker 1995; see also Becker 1974). For my visual studies of urban neighborhoods, the context is urban sociology. As to your correct observation that I favor the notion of "vernacular," it is indeed because it operates "outside the control of political decisions and produces unstable forms." The main thrust of my visual studies is demonstrating how ordinary people change the meaning of spaces and places by changing what those spaces and places look like, both to themselves and especially to outside observers. I should note that in my work, I include people and their social activities in the visual frame as part of the vernacular landscape. I am interested in how the way a space is being used, that is, what is visibly going on in the space, changes its meaning - for example, how a homeless person creates a home in a doorway, or the presence of people, especially women, wearing traditional or religious clothing.

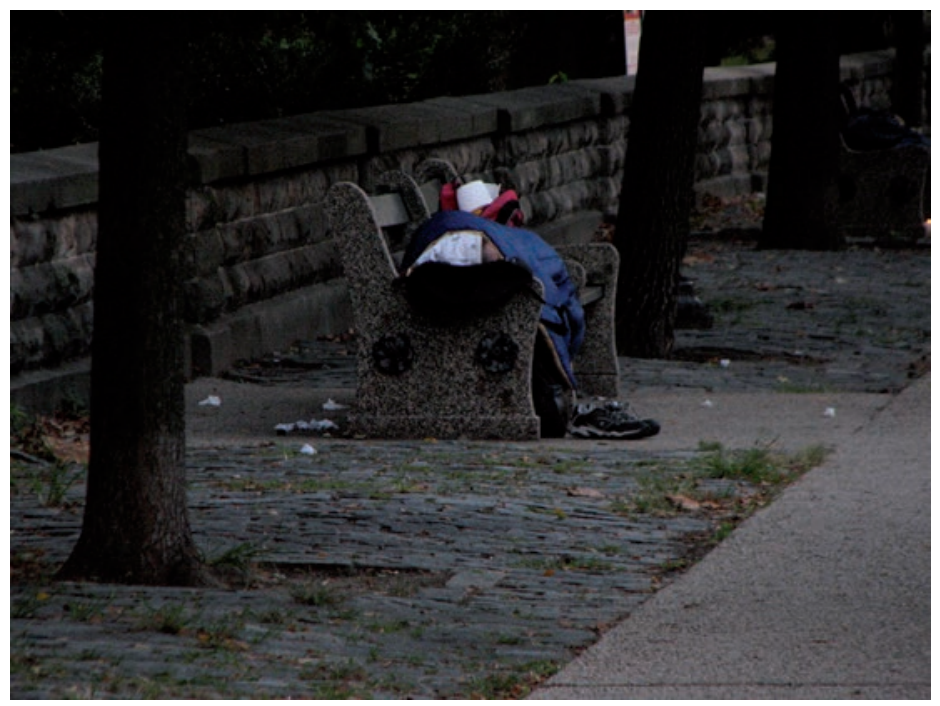

Figure 4. Homeless, Prospect Park West, Brooklyn, New York, 2016. I often come across the homeless in cities around the world. Sometimes in public parks, but most visible are those on the street. In this scene, a person has created a place to sleep on a park bench in the very fashionable neighborhood of Park Slope, Brooklyn, New York. C Jerry Krase. 
Since it fell outside the normal scope of sociology, I borrowed liberally from a wide range of scholars to support my work that showed how cultural traits are visually available as social performances in vernacular architecture. For example, Mike Davis showed how Latinos practicing Latinidad "reinvented" Los Angeles, and called for the exploration of the role of ethnicity in space and place (Davis). For Anthony Giddens it is "Human Agency" which transforms that representation into practice though continuous social action within the constraints of structure (Giddens). His idea tracks closely to "notions of precarious, informal, and spontaneous." Erving Goffman might also argue that the way that all ethnics present themselves on the street can be viewed as practice as well as representation (Goffman 1959). It is their own agency which transforms mere representation into practice. My own and these as well as many other insights blend easily with Pierre Bourdieu's notion of "habitus" and of "taste" which are visible in the vernacular landscape, as for me the landscape includes people and social activities (Bourdieu 1984 and 1977). In this regard, Mark Gottdiener wrote of the spatial semiotics of the settlement spaces "built by people who have followed some meaningful plan for the purposes of containing economic, political, and cultural activities, in which people $[\ldots]$ organize their daily actions according to meaningful aspects of the constructed space" (Gottdiener 15-16; see also Lofland 1985 and 1998). More recently, I have learned to appreciate parallels in the works of those beyond my own discipline of sociology, such as the geographer F. Pierce Lewis' "Axioms for Reading the Landscape" - for instance The Axiom of Common Things, which has been obvious in my work: "Common landscapes - however important they may be - are by their nature hard to study by conventional academic means. The reason is negligence, combined with snobbery" (Lewis 8).

JB/EL: Several of your publications and many of your photographs show how ways of dwelling and commercial patterns imported from foreign cultural areas get acclimatized to the New York City context. Do you think that this type of convergence between the local and the extraneous is a fertile ground for the emergence of vernacular practices, in opposition to the idea that the vernacular is generated by isolated communities using local resources?

JK: As I have consistently argued, immigrants express their own agency, via visible spatial practices, to change the meanings of the spaces and places they occupy and use. And, though not the most powerful local agents in our "glocalized" world, they nevertheless sometimes successfully compete with others to visually define their localities. As suggested by Jackson, I have paid special attention to commercial vernacular landscapes such as markets and other shopping areas because they most often serve in urban areas as "markers" of changes due to migration. It might also be useful for us to think with David G. Gutiérrez of immigrant neighborhoods as "Third Spaces" or interstitial places where things such as ethnic identity are created and then negotiated, demonstrating in this way the agency of ordinary people (Gutiérrez). I have tried to demonstrate this in many places starting with my first article, on the traces I found of Italian vernacular landscapes in Italian American neighborhoods (Krase 1993). 
What I found was that groups like southern Italian peasants have created distinct landscapes and places that suited them even when the environments in which they settled were previously established. The resulting designs of their neighborhoods are rich enough for many subgroups to claim a territory. If we look carefully at these communities, we can see that the way space is used is at least as important as how it was originally constructed or subsequently altered. As immigrants assimilate, they adopt the environmental values of the dominant society. Therefore, only limited "traces" or mere "architectural vestiges" of the original home territorial values can be found in the resulting landscapes and places. Some of the most important visible elements of Italian and Italian American neighborhood culture I discovered were small-scale and arranged so as to facilitate intrafamily relations, and the supremacy of private over public values in regard to territory and activities in local spaces. A common expression of this is the appropriation of public spaces such as sidewalks or streets for private uses, as seen in figures 5 and 6 below.

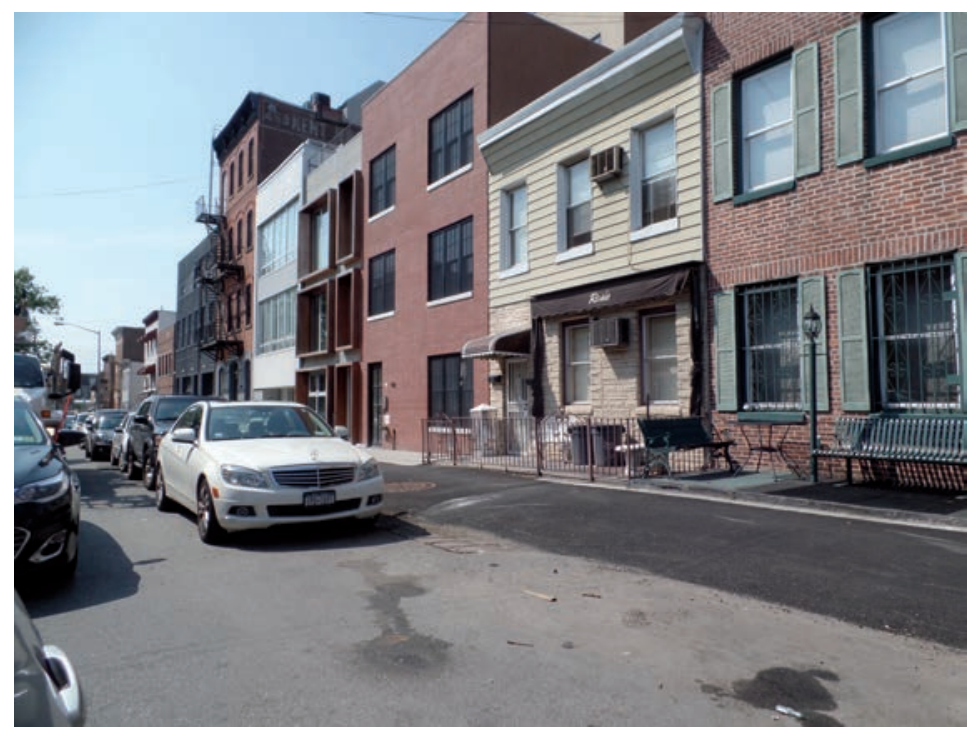

Figure 5. Carroll Street, Italian American Enclave, Carroll Street, Brooklyn, New York, 2015.

Although the Italian American population of Brooklyn has been in decline for several decades, remnants of its once large neighborhoods remain, such as this portion of Carroll Street, in which upscaling, or gentrification, can be seen. I have found in my visual studies of Italian and Italian-American residential communities, that a common characteristic is the appropriation of public space for personal use. Here we see, for example, private benches, a table, a shrine and a bird bath encroaching on the narrow pedestrian sidewalk.

(C) Jerry Krase. 


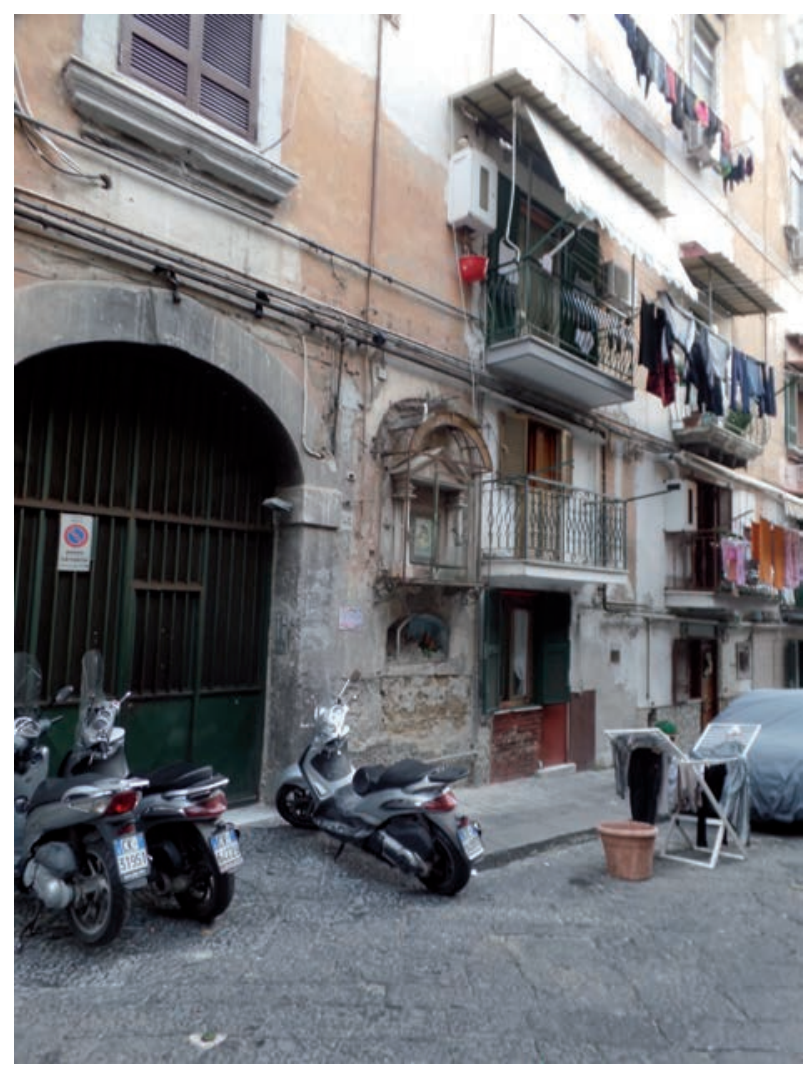

Figure 6. Quartiere Spagnolo, Naples, Italy, 2015.

I have conducted many visual studies in Italy to compare with Italian American enclaves, such as that on Carroll Street. In this photo, a clothes-drying rack placed in the street is an obvious example of spatial appropriation that is common in Italy's densely settled neighborhoods; typically with narrow streets, and little in the way of pedestrian walkways.

(c) Jerry Krase. 
JB/EL: After studies carried out before World War II, such as Margaret Bourke-White's photographs of signs and billboards, the unplanned landscapes of commercial strips have been presented as the most emblematic articulation of the "new vernacular." This contemporary, commercial vernacular is very salient in Jackson's work, in Robert Venturi, Denise Scott Brown and Stephen Izenour's Learning from Las Vegas (1972), or in Stephen Shore's images. It is also the basis of stringent criticism of the aesthetic degradation of the American landscape for instance in the work of the architect Peter Blake (God's Own Junkyard, 1964) and of F. Pierce Lewis (Visual Blight in America, 1973). By contrast, this kind of vernacular has been much less studied - and photographed - in multifunctional neighborhoods that mix housing and commercial activities. What do you learn when you photograph shops and their signs?

JK: You are correct in asserting that much can be learned by the study of commercial strips and I have published quite a bit on commercial strips in many contexts such as gentrification as well as ethnic enclaves. Also, although I have spent a considerable amount of time photographing what some regard as kitsch, vulgarity, and otherwise aesthetic blight found in the work of those you cite above, and can relate to their sensibilities, my role as a social scientist is not to judge these landscapes but to try to understand how they come into being. I recall reading Pierre Bourdieu for example and feeling quite unhappy (insulted perhaps as an aspirant to middle-class status) with his unkind commentary on middle-brow tastes (Bourdieu 1984, 16, 58). Also, as I don't consider myself a photographer I don't feel I have earned the position to judge aesthetic "degradation." In this regard I would refer back to my earlier reference to Becker and the social science rather than art context of my image-making. I must say that I have photographed extensively in and around Las Vegas and other "simulated" places, especially on The Strip, where attempts have been made to create Italian themes such as the Bellagio, the Venetian, and Caesar's Palace. At the same time, as to more common vernacular landscapes, I have looked as well at the advertising of sex work and the neighborhoods of workers in Las Vegas. As to billboards, junkyards, and other visual "blight," I have photographed them, but mainly as they are connected to specific locations or social processes in which I have been interested. For the most part, commercial streets in residential urban neighborhoods are the result of both local and extra-local forces. My work is not a commentary on the aesthetics of what can be seen on these streets, if you will, but of how and why local residents and merchants create them; the sights they create come from their social and cultural stores of knowledge. However, one can find in these neighborhoods, and on the major pathways to them, the intrusion of sights such as corporate or more local business billboards - for example, along the interstate highways in Brooklyn that often border working-class neighborhoods. It is more interesting to note that corporate signage, such as for telephone or other services, tries to be ethnically sensitive to its local audiences by, for example, being expressed in dominant non-English languages and symbolism. 
Figure 7. Visual Signs of NYC Financial Crisis, Brooklyn, New York, 2010.

A faded sign on a newly stuccoed building wall signals that business still goes on, even in distressed neighborhoods. (c) Jerry Krase and Timothy Shortell.
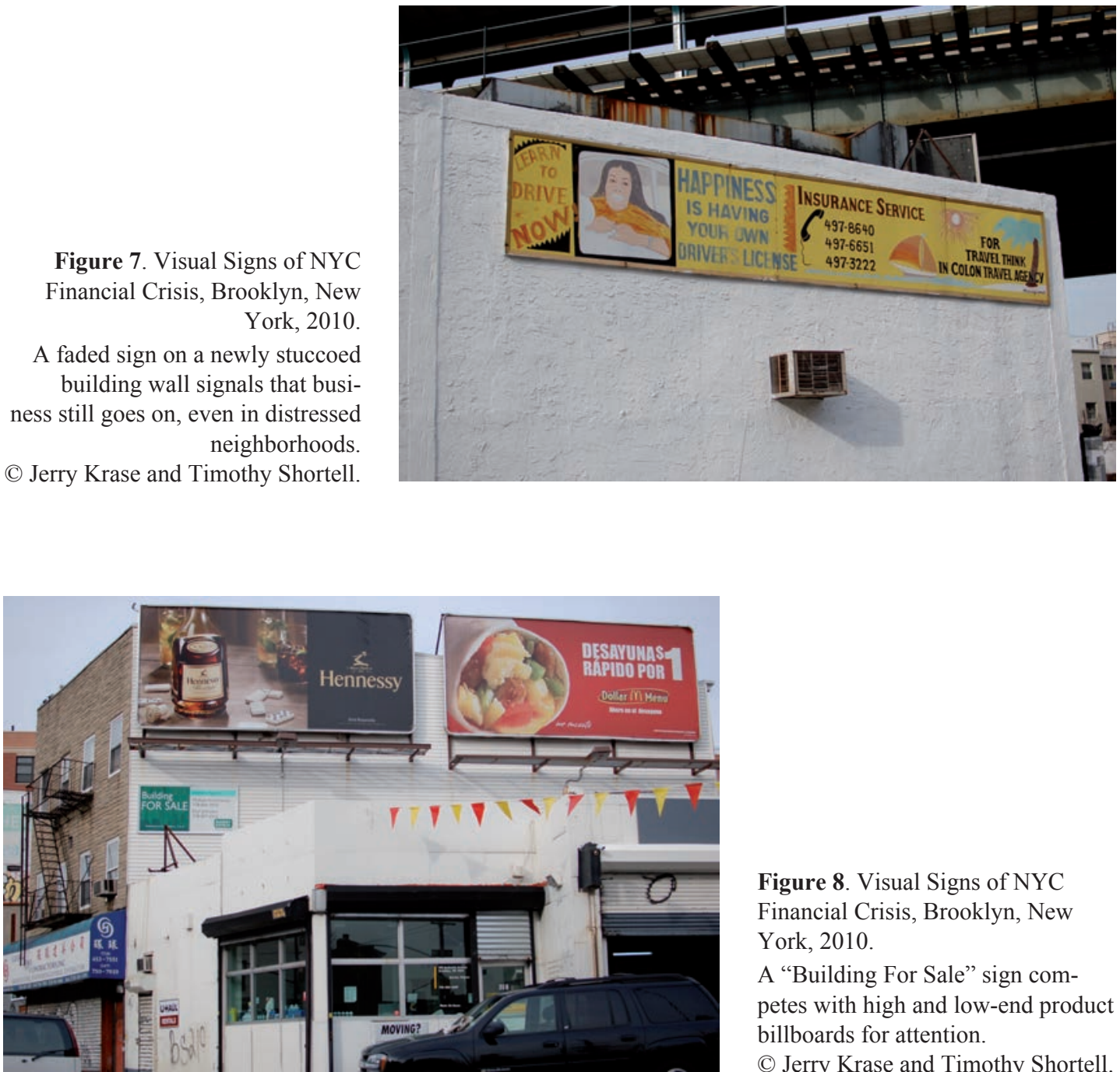

Figure 8. Visual Signs of NYC Financial Crisis, Brooklyn, New York, 2010.

A "Building For Sale" sign competes with high and low-end product billboards for attention.

(c) Jerry Krase and Timothy Shortell. 
JB/EL: Another central focus of your research is gentrification and how it materializes in the urban landscape. Do you think that gentrification leads to a retraction of the vernacular, or is the vernacular "digested" by a gentrification process that turns it into an aesthetic object?

JK: I have a large collection of photographs of neighborhoods defined in various ways, such as demographically, by social science literature, popular media, or by the real estate industry, as gentrified or gentrifying. In "Poland and Polonia: Gentrification as Ethnic Aesthetic Practice and Migratory Process" (Krase 2005), I attempted to show some of the visual similarities in commercial vernacular landscapes of gentrified places by holding constant the ethnic dimension and describing them as a matter of Bourdieu's Tastes of Luxury or Necessity - a Distinction that helps us understand how spaces become more attractive to more privileged consumers of housing, goods, and services (Bourdieu 1984, 174-75). This also involved looking for symbolic expressions of class position, aesthetic tropes, or specific types of commercial establishments typical of gentrification that are indicators or semiotics of upscaling such as coffee shops serving cappuccino (Atkinson; Zukin). I think of gentrification as a shift in semiotics or the meaning of the space/place as opposed to merely the physical alteration in the space/place. It is a movement from a taste of necessity to a taste of luxury. It should be noted that in some cases the vernacular of ethnic or immigrant or working-class neighborhoods, the patina, or ambiance if you will, is commodified but at the same time tamed or domesticated, i.e. "themed," for the enjoyment or entertainment of tourists (Krase 2005, 187-8; see also Krase 2019).

JB/EL: In 2011, you photographed the effects of the financial crisis on Brooklyn's landscape, defined both as real-estate and as a social scene, while paying special attention to provisional and makeshift spatial arrangements. You published in 2013 with Timothy Shortell a photographically-illustrated text entitled "Seeing New York City's Financial Crisis in the Vernacular Landscape" (Krase and Shortell 2013). Would you say that a precarious real-estate and economic situation has spawned an extension of the vernacular domain?

JK: Although the article was "illustrated," more importantly for our social scientific peers, we first researched the zones we subsequently visually surveyed that were identified by municipal and other data as distressed. Then we drove several miles up and down all the streets in the district. Although not a statistical selection from a large random sample, the examples for the published article were chosen for their visual "power." The real estate for sale, the easy mortgage signs, and the boarded up buildings are direct signs of the distress, but the economic downturn also provided the opportunity for artists and landlords to repurpose empty shop windows in abandoned stores for sidewalk art galleries. The article also highlighted how the creations of ordinary people could become more apparent as, for example, the way locals appropriated vacant lots and built gardens on them. The financial crisis also increased the number of derelict buildings whose exterior walls were canvases for graffiti artists. 


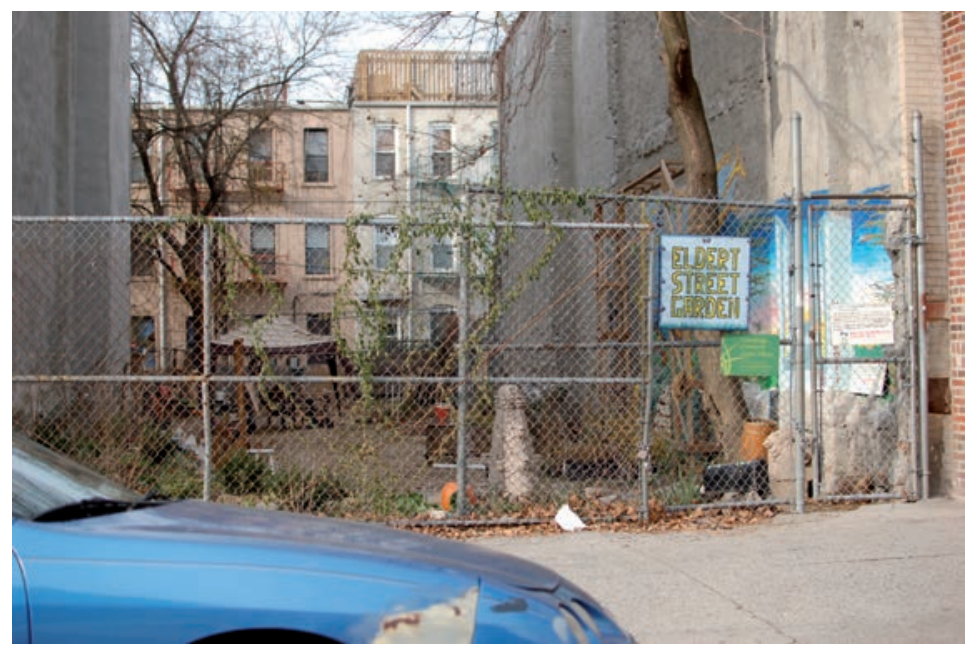

Figure 9. Visual Signs of NYC Financial Crisis, Brooklyn, New York, 2010.

A vacant lot has been taken over by local residents and turned into a community garden.

C Jerry Krase and Timothy Shortell.

JB/EL: In your work, you have linked the notion of the vernacular to stigmatized people and places. According to Jackson, the vernacular is created by "proletarians" or "unskilled wage earners." Would you say that vernacular productions, both as material forms and forms of social occupation of the urban space, are part of what produces stigmatization? Are the streets, signs, and domestic arrangements that you photograph expressions of a "proletarian" culture?

JK: For me, and I believe also for Jackson, vernacular landscapes are not limited to "proletarians." In some cases, middle and even high classes have the capacity to produce their own vernaculars that reflect their cultural backgrounds and interests. Also, it must be remembered that in most cases, the stigma is applied by the viewer, not by the inhabitants who can see their own neighborhoods, and especially the vernacular landscapes they have produced within them, in a positive light. I have written quite a bit on the notion of stigma which I have adopted from Erving Goffman (1963) to apply in analyses and practical work on African American neighborhoods for example, beginning with my 1973 doctoral dissertation "The Presentation of Community in Urban Society". Since that time, I have continued to help mediate between local organizations and government agencies on such issues as immigration 
and displacement, where an understanding of local vernacular landscapes, and their meaning to local residents, is invaluable.

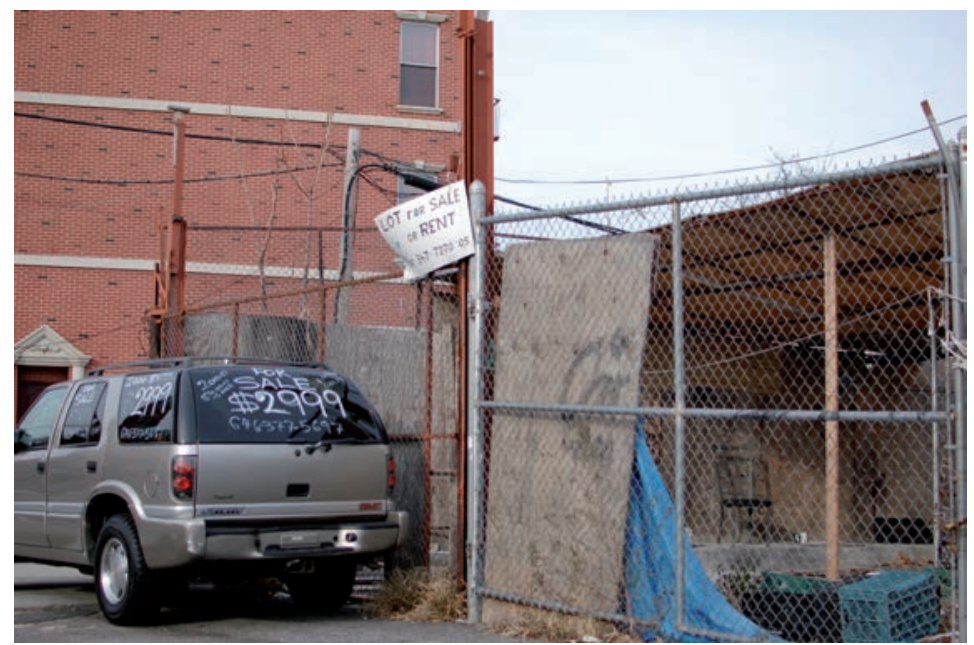

Figure 10. Visual Signs of NYC Financial Crisis, Brooklyn, New York, 2010. There are many vacant lots, buildings for sale or rent in the neighborhood. (C) Jerry Krase and Timothy Shortell.

JB/EL: In many of your photographs of Brooklyn - for instance those shot in Carroll Gardens and Greenpoint - you focus on domestic appropriations of public space that amount to the closing off of part of the sidewalk and eventually to its privatization. Would you say that the interface between public and private space is a key area for the materialization of the vernacular in urban contexts?

JK: For me, the interface between public and private spaces is central, because I limit my work to that interstitial zone. The ethics of my profession require that, for example, I only use photographs of people who are in publicly accessible spaces. I don't usually photograph over fences or through peep holes, and if I did I wouldn't share those images. However, with permission, I have shot such private and interior spaces not easily available to public view. I am currently working on a project showing how some of these spaces have been repurposed because of the restrictions on public space imposed by the COVID 19 pandemic (2020). As to domestication, homeowners and renters have taken over the sidewalks in front of their residences, by placing chairs and tables and in one case working there on their 
computer. In a sense this is an extension of the interior domestic space which is now in public view. In a related vein, in New York City, restaurants have been given permission to construct outdoor eating areas in the streets near their establishments, changing both the use and appearance of the public space.

Figure 11. Country House, Polish American Enclave, Greenpoint, Brooklyn, New York, 1994.

While documenting this Polish American enclave, I was attracted to the symmetry and decoration of this front space. Although similar in some ways to the Italian American house fronts on Carroll Street (Fig. 5 ), this seemed more of a display for the passers-by than for the personal use of the occupants. (I discussed these similarities and differences in

Krase 1997.)

(C) Jerry Krase.
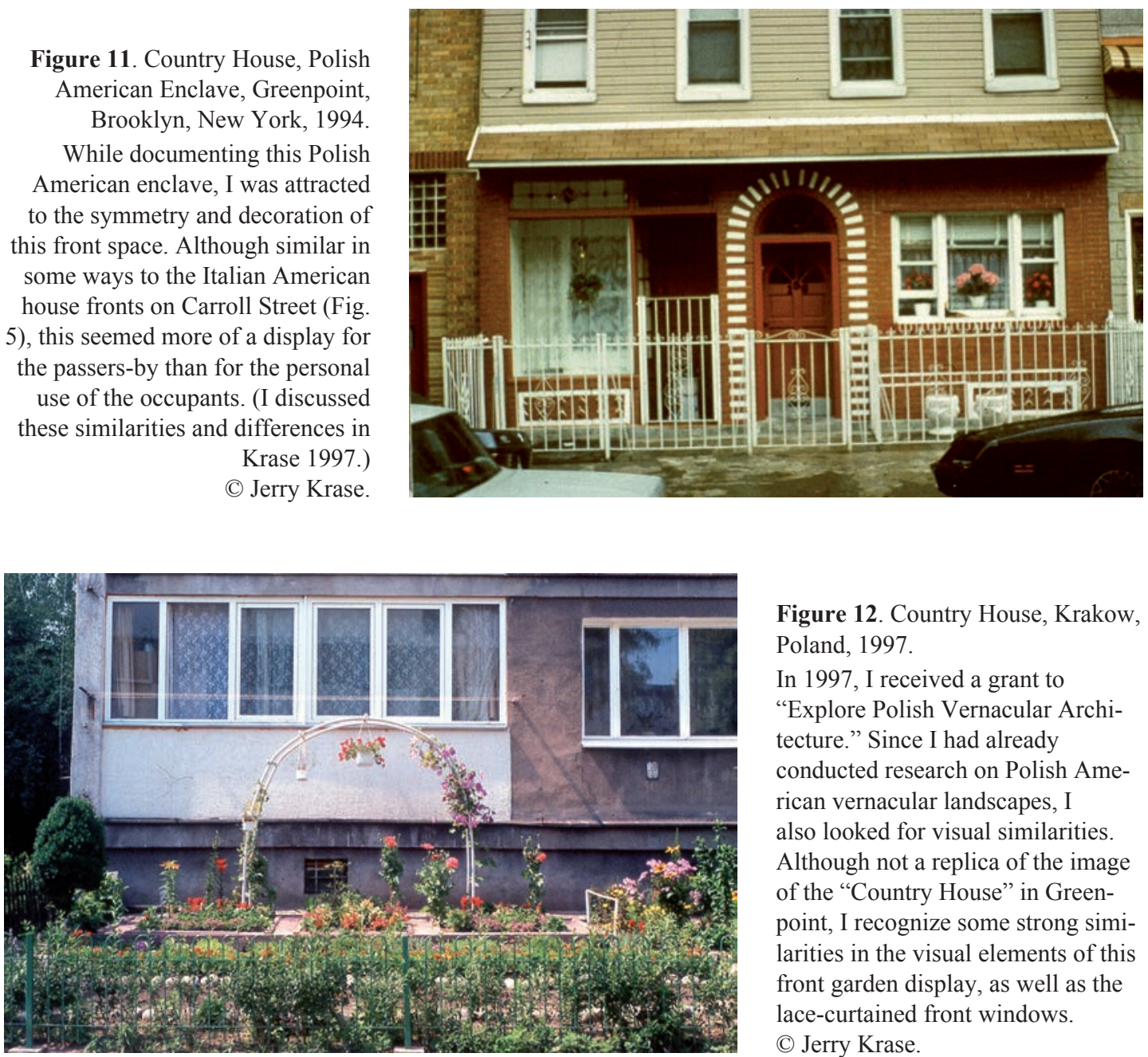

Figure 12. Country House, Krakow, Poland, 1997.

In 1997, I received a grant to "Explore Polish Vernacular Architecture." Since I had already conducted research on Polish American vernacular landscapes, I also looked for visual similarities. Although not a replica of the image of the "Country House" in Greenpoint, I recognize some strong similarities in the visual elements of this front garden display, as well as the lace-curtained front windows. (c) Jerry Krase. 


\section{Photography and fieldwork}

JB/EL: As evidenced in your work, photography allows for the documenting of precarious arrangements and limited agency - including in contexts where it is not feasible to "establish" things. But do more established and less visible social structures evade the photographic, exterior gaze? In your own practice, is visual documentation connected to other forms of qualitative research, like interviews or informal conversations, that could then influence your photographic practices and produce other layers of photographs of the same reality?

JK: Depending on the project, I use many different types of data to inform my descriptions and analyses of what you refer to as "reality." For example, in studying the vernacular landscapes of Chinatowns, I incorporate many types of information such as demographic and historical data to first identify the place and its parameters. I would have to admit that other, non-visual sources of information on a subject such as gentrification or particular neighborhoods can influence the decisions I make as to how to proceed. For example, my choices of the Chinatowns that I have researched and photographed have often come from academic colleagues with familial connections to them. These conversations have sometimes led me to look for things that I would not have been aware of as important to, at least their memories of, the places. This is especially important in the case where my language competence is limited. In other cases, community organization contacts have been very valuable to locate less obvious places of interest.

JB/EL: A significant part of your work centers on Brooklyn, where you live. To what extent does your practice of visual sociology rely on everyday observation - with the naked eye, or with a camera? To what extent is the camera, as an autonomous piece of equipment or as cell phone, part of everyday life for you?

JK: Modern technology has made it possible to carry a camera almost everywhere I go and I am always on the lookout for scenes that interest me, for example the presence of homeless people colonizing urban spaces which I have captured in major cities around the world. In a way, photographic research has become a part of my everyday life. Even when I neglect to take my cell phone with me, I may see something for which to return to at a later date and photograph. As to more formal documentation or study, if I have the time and opportunity, I first do a walk through and take photographs that are more of a survey, and then back track to focus in on a particular aspect of the scenes. When I teach my visual research methods, I encourage my students to look first with their eyes before raising the camera, as I believe the camera limits our vision and much can be lost in the process if the scene is only viewed through even the widest angle lens. Even when examining my own photos, I discover things that I did 
not see at first glance - although having a camera set to infinity focus is helpful in this regard. Current technologies make it possible to digitally change the focus, etc., after taking the shot.

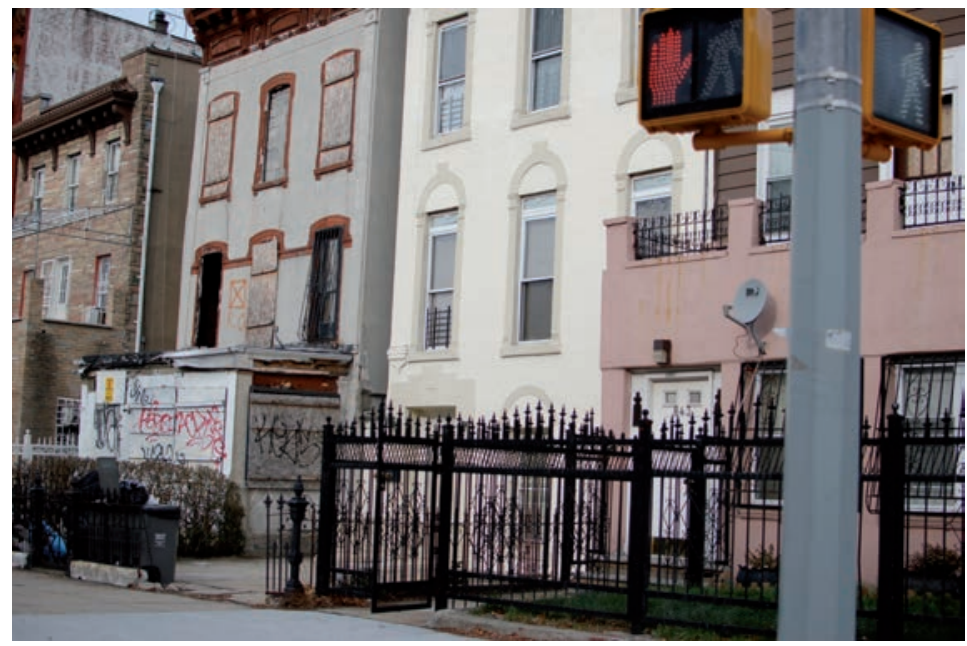

Figure 13. Visual Signs of NYC Financial Crisis, Brooklyn, New York, 2010.

An abandoned building slated for renovation sits among other well-tended, occupied homes.

(c) Jerry Krase and Timothy Shortell.

JB/EL: You also photograph foreign cities, where you spend much less time. Do you have different modes of observation and documentation when you do not have an intimate knowledge of the environment?

JK: Although you might say that Brooklyn and New York City are my "beat," I have spent a great deal of time in foreign cities, and conducted repeat photography in many of them. The number of photographs in my research archive outside of the USA is actually far greater than those within it. In most cases, my visual research is not done on the blind. However, there are many cases, such as the walk we took together in Paris, when I take as many photographs as possible, with or without instruction, and later look at other data to provide context for them. I might say that having walked through so many cities, there is little that I see which is not immediately or retroactively "recognizable." 


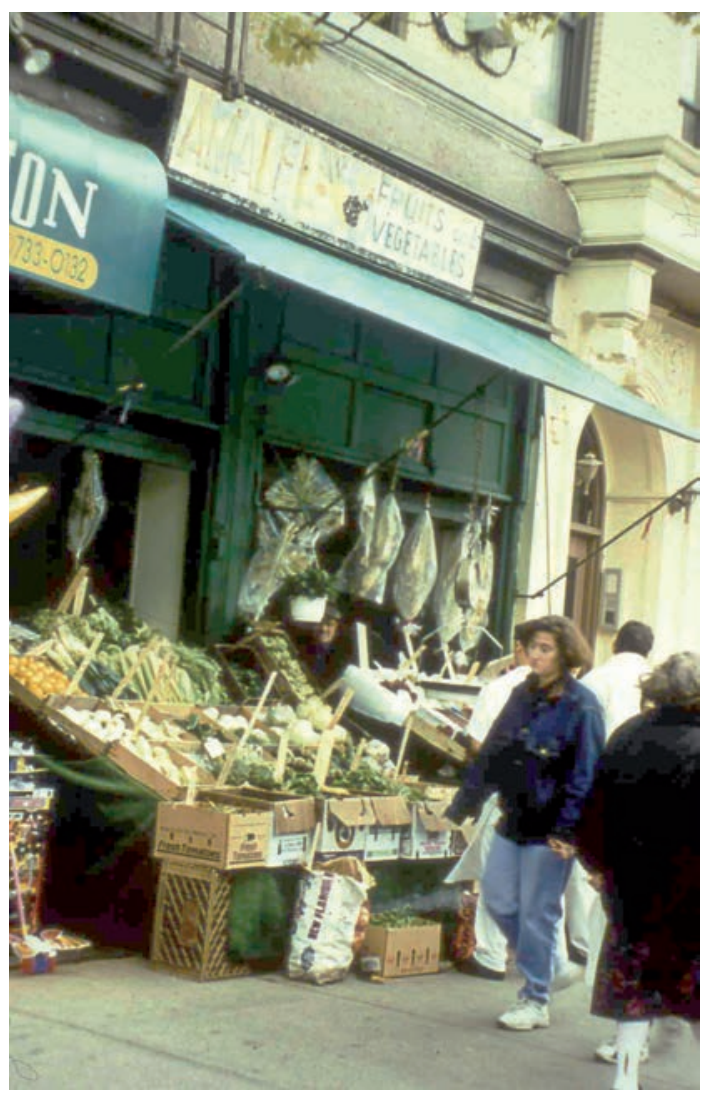

Figure 14. Fruit \& Vegetable Store, Italian American Enclave, Belmont, The Bronx, New York, 1998.

In 1997, as part of a larger project to document New York City's waning Italian American enclaves, I took this photo of a rather ordinary-looking retail store and its rather dog-eared "Amalfi Fruits \& Vegetables" store sign.

(c) Jerry Krase.
JB/EL: Is the way you photograph part of a specific methodology (or several methodologies), or does it amount to one? Would it be wrong to say that you use photography primarily to take notes and produce visual data?

JK: It would not be wrong to say that my photographs serve as notes and visual data to be used for descriptions and analyses. For example, I take photos of street signs to relate to maps of the area. This is especially helpful when I was not adequately prepared for the shoot. Most often however, the photographs were taken for a very specific geographic project or they are taken for an ongoing project such as gentrification or migration. In all cases, they are combined with other types of data and references that include newspapers and other media. Although not nearly as striking as the work of Camilo Jose Vergara (1995; 2013), for example, I used repeat photography to capture social change in a recent study about a Scandinavian commercial strip in Brooklyn that became a Chinese one (Krase and Shortell 2020). In deference to Vergara, I should also note that I have been photographing the changes on $116^{\text {th }}$ Street in New York City's Spanish Harlem for several decades. But although I take a lot of pictures, I am not a photographer - my repeat photographs, for example, are sometimes taken many years apart with different instruments and under very different circumstances.

JB/EL: In early 2020, we walked for a few hours around the Porte Saint-Denis in Paris. This walk might have become what you call a "photo-walk," as you took many pictures in what looked like a form of visual note-taking. Can you explain to us 
how you store - or archive - your photographs, how you organize them, in order to then select some of them and use them in your research and teaching?

JK: Whenever I take such a walk I think of Michel de Certeau creating the city in the course of movement through it (Certeau 129). I mention "movement" because there are other modes I have used to survey scenes, doing my shooting out of car windows, on bicycles, and on public transport. In Berlin, for example, I did a city circuit on outdoor public transport (buses and elevated UBahn) (Krase 2011). As the result of your tour, I have been able to compare my images with other more or less similar migrant spaces, ordinary commercial districts, and expressions of gentrification. I saw some good examples of South Asian and African commercial establishments that I can compare to other cities. Also, the photos I took on our walk through the [Passage Brady] arcade will be added to my own "Arcades Project," with apologies to Walter Benjamin (1999), that I have written about (Krase 2012). Serendipity is not a methodology, but the subsequent examination of the images as data, for example as a comparison, or addition to a collection, is. I am now in the process of organizing all my images which I have been more or less systematically collecting since the mid-1960s. The earliest, as you might expect, are prints, negatives,

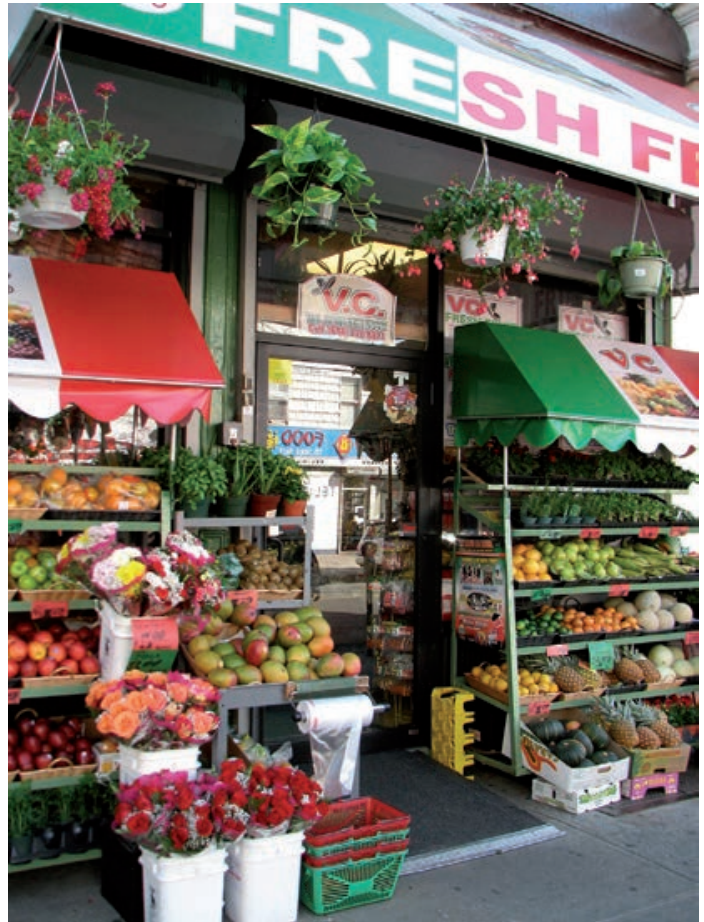

Figure 15. Fruit \& Vegetable Store, Italian American Enclave, Belmont, The Bronx, New York, 2004.

In 2004, I returned to Belmont to rephotograph its commercial streets and discovered that the rundown "Amalfi Fruits \& Vegetables" store had been brightly renovated and its ethnic motif dominated by the Tricolore of the Italian flag.

(C) Jerry Krase. and slides which I have placed in archival pages.

Since 2007, my cameras have been exclusively digital. Although it is easier to conduct research with digital cameras, one tends to take many more photographs than in the past with film both because it is less expensive but also because of the ease of shooting. The result has been a mass of thousands 
of images to add to my previous, more discriminating, collection to read and analyze at a later date. For several years now, I have been slowly digitizing the earlier images by scanning them. All of the digitized photographs, and scans, are stored on my computers, external hard drives, and several online storage sites. Currently the crude organization for both tangible and digital images is first by date and then by location. Within those parameters I am organizing them by sociological processes such as gentrification and immigration, and by themes such as Ethnic Enclaves, including Little Italies and Chinatowns. It is possible to add data, or tags, to digital collections, which would make it much easier to do cross-referencing. That would also facilitate locating images and doing repeat photography for longitudinal studies, or cross-national comparative study. For example, I recently conducted a visual sociology workshop in Krakow, Poland, on Upscaling and Gentrification between 1997 and 2017. There, Jagiellonian University doctoral students were provided with my 1997 photos and were asked to select them to reshoot and discuss the changes in appearances and, more importantly, what might account for the changes such as gentrification of the areas.

JB/EL: The examination of the archives of other researchers who have worked on the vernacular, such as John Brinckerhoff Jackson, Richard Longstreth, and Chester Liebs, has revealed that they would often give or exchange their own slides without indicating who had produced them. Neither personal documents nor finalized work, their photographs are closer to raw material. Is it significant to you that you are the author of your photographs, or can they be circulated without being specifically traced to the person who took them?

JK: As a social scientist, I am sure that knowing not only who took the picture, but also their biography, training, and reputation, makes a difference. Many progressive social science journals now require reflexive statements so that readers can impute their biases. In the example you give, I would assume that this was a feature of their social and not merely professional relationships. Although this is not in your question, I must note that using the work of others without their knowledge and permission is a major violation of my professional ethics, although I do understand the sentiment. Between my colleague Timothy Shortell and I, sometimes it is hard to remember which photo is whose. For example, for the financial crisis article, I drove and we passed my camera back and forth to shoot out of different sides of the car. Sometimes we use our own cameras and when we collaborate on an article the photos chosen are properly credited. We also maintain different archives for our individual photo and other visual work. 


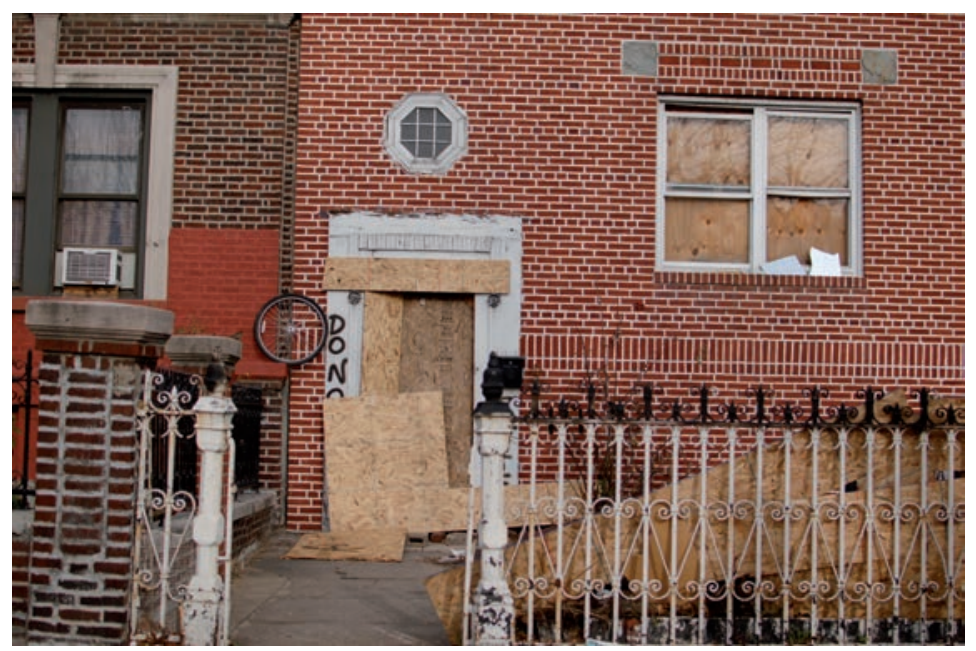

Figure 16. Visual Signs of NYC Financial Crisis, Brooklyn, New York, 2010. This distressed residential building is slated for extensive renovation. (C) Jerry Krase. 


\section{WORKS CITED}

ATKINSON, Rowland. "Domestication by Cappuccino or a Revenge on Urban Space? Control and Empowerment in the Management of Public Spaces." Urban Studies 40.9 (2003): 1829-43.

BECKER, Howard S. "Photography and Sociology." Studies in the Anthropology of Visual Communication 1.1 (1974): 3-26.

BECKER, Howard S. "Visual Sociology, Documentary Photography, and Photojournalism: It's (Almost) All a Matter of Context." Visual Sociology 10.1-2 (1995): 5-14.

BENJAMIN, Walter. The Arcades Project. Cambridge, Massachusetts: Harvard University Press, 1999.

BOURDIEU, Pierre. Outline of a Theory of Practice. 1972. Transl. from the French by Richard Nice. New York: Cambridge University Press, 1977.

BOURDIEU, Pierre. Distinction: A Social Critique of the Judgement of Taste. 1979. Transl. from the French by Richard Nice. Cambridge, Massachusetts: Harvard University Press, 1984.

CERTEAU, Michel de. "Practices of Space." 1980. Transl. from the French by Richard Miller and Edward Schneider. On Signs. Ed. Marshall Blonsky. Baltimore: Johns Hopkins Press, 1985. 122-45.

DAVIS, Mike. Magical Urbanism: Latinos Reinvent the U.S. City. London: Verso, 2001.

GIDDENS, Anthony. The Constitution of Society: Outline of the Theory of Structuration. Cambridge: Polity, 1984.

GOFFMAN, Erving. The Presentation of Self in Everyday Life. Garden City: Doubleday and Company, 1959.

GOFFMAN, Erving. Stigma: Notes on the Management of Spoiled Identity. Englewood Cliffs, New Jersey: Prentice-Hall, 1963.

GOTTDIENER, Mark. The Social Production of Urban Space. $2^{\text {nd }}$ ed. Austin: University of Texas Press, 1994.

GUTIÉRREZ, David G. "Migration, Emergent Ethnicity, and the 'Third Space': The Shifting Politics of Nationalism in Greater Mexico." Journal of American History 86.2 ("Rethinking History and the Nation State: Mexico and the United States" 1999): 481-517.

JACKSON, John Brinckerhoff. Discovering the Vernacular Landscape. New Haven: Yale University Press. 1984.

KRASE, Jerome. The Presentation of Community in Urban Society, doctoral dissertation. New York University. Ann Arbor, Michigan: University Microfilms \#74 1916, 1973.

KRASE, Jerome. “Traces of Home.” Places: A Quarterly Journal of Environmental Design 8.4 (1993): 46-55.

KRASE, Jerome. "Polish and Italian Vernacular Landscapes in Brooklyn." Polish American Studies 56.1 (1997): 9-31. 
KRASE, Jerome. "Poland and Polonia: Gentrification as Ethnic Aesthetic Practice and Migratory Process." Gentrification in Global Perspective. Ed. Rowland Atkinson and Gary Bridges. London: Routledge, 2005. 185-208.

KRASE, Jerome. "Life in the Time of Covid19 in a Hyper-Super-Gentrified Neighborhood: Making Things Visible." Urbanities-Journal of Urban Ethnography 10 ("City Life and Beyond in Times of Pandemic," ed. G. B. Prato, 2020): 69-75.

KRASE, Jerome. “Berlin.” Streetnotes 19.1 (2011): 89-101.

KRASE, Jerome. Seeing Cities Change: Local Culture and Class. Farnham: Ashgate, 2012.

KRASE, Jerome and Timothy SHORTELL. "Seeing New York City's Financial Crisis in the Vernacular Landscape." Cities and Crisis: New Critical Urban Theory. Ed. Kuniko Fujita. Thousand Oaks: SAGE Publications, 2013. 188-217.

KRASE, Jerome. "Theme Parks.” The Wiley-Blackwell Encyclopedia of Urban and Regional Studies. Ed. Anthony M. Orum. Hoboken, New Jersey: John Wiley and Sons, 2019.

KRASE, Jerome and Timothy SHORTELL. "Storymaking and Photography: The Visual Essay and Migration." Visual Methods in Migration Studies. Ed. Karolina Nikielska-Sekula and Amandine Desille. Amsterdam: Springer, Forthcoming 2020.

LEWIS, F. Pierce. “Axioms of the Landscape: Some Guides to the American Scene,” Journal of Architectural Education 30.1 ("Teaching the Landscape" 1976): 6-9.

LOFLAND, Lyn. A World of Strangers: Order and Action in Urban Public Space. Prospect Heights, Illinois: Waveland Press, 1985.

LOFLAND, Lyn. The Public Realm: Exploring the City's Quintessential Social Territory. New York: Aldine Gruyter, 1998.

SCULLY, Vincent. American Architecture and Urbanism. New York: Praeger. 1969.

VERGARA, Camilo J. The New American Ghetto. New Brunswick: Rutgers University Press, 1995.

VERGARA, Camilo J. Harlem: The Unmaking of a Ghetto. Chicago: University of Chicago Press, 2013.

ZELINSKY, Wilbur. The Culture Geography of the United States. Englewood Cliffs, New Jersey: Prentice Hall, 1973.

ZELINSKY, Wilbur. The Enigma of Ethnicity Another American Dilemma. Iowa City: University of Iowa Press, 2000.

ZUKIN, Sharon. The Cultures of Cities. Oxford: Blackwell, 1995. 
